\title{
Medicinal Properties of Chamomile against Dysmenorrhea
}

\author{
Sadia Mujtaba Khan, Fatima Farooq and Sidra khalid* \\ Faculty of Allied Health Sciences University Institute of Diet and Nutritional Sciences, The University of Lahore, Pakistan \\ *Corresponding author: Sidra khalid, University Institute of Diet and Nutritional Sciences, Faculty of Allied Health \\ Sciences, The University of Lahore, Lahore, Pakistan
}

\begin{tabular}{|c|c|}
\hline ARTICLE INFO & ABSTRACT \\
\hline Received: 榓 February 10, 2021 & $\begin{array}{l}\text { Chamomile is sweet and small flowers which reduce inflammation in our body and it } \\
\text { also have anticonvulsant properties. Matricaria Chamomile and Chamomile Recutita are }\end{array}$ \\
\hline Published: 慧 February 18, 2021 & the scientific name of Chamomile two species. Chamomile is also known as the miracle \\
\hline $\begin{array}{l}\text { Citation: Sadia Mujtaba Khan, Fatima } \\
\text { Farooq, Sidra khalid. Medicinal Properties } \\
\text { f Chamomile against Dysmenorrhea. } \\
\text { Biomed J Sci \& Tech Res 34(1)-2021. } \\
\text { BJSTR. MS.ID.005490. }\end{array}$ & $\begin{array}{l}\text { anti-diuretic, for treating stomach aches, reduction of the dysmenorrhea, anti-allergens, } \\
\text { anti-malaria, anti-fever and for the jaundice. Dysmenorrhea means menstrual pain, which } \\
\text { is not a disease, it is a condition by which women feel discomfort periodically in their } \\
\text { menstrual cycle. There are two types of dysmenorrhea. In primary dysmenorrhea there } \\
\text { is not any type of abnormality and in secondary dysmenorrhea gynecological problems } \\
\text { which causes pain and cramps. The prevalence of the dysmenorrhea is } 50-90 \% \text { women }\end{array}$ \\
\hline $\begin{array}{l}\text { Keywords: Chamomile; Dysmenorrhea; } \\
\text { Primary dysmenorrhea; Secondary } \\
\text { dysmenorrhea }\end{array}$ & $\begin{array}{l}\text { suffer from these conditions respectively. Women have been used contemporary therapies } \\
\text { to treat dysmenorrhea which includes herbal therapy (use of chamomile in form of tea } \\
\text { and essential oil), physiotherapy, yoga and heat. Because in terms of treatment, such as } \\
\text { non-steroidal anti-inflammatory drugs and oral contraceptives are not always effective in } \\
\text { treating dysmenorrhea. So there is immerse need of herbal medicines such as chamomile } \\
\text { in form of tea and oil to treat dysmenorrhea }\end{array}$ \\
\hline
\end{tabular}

\section{Introduction}

From the centuries herbs and flowers are used for the benefits of the health but it has been increasing from last 20 years. Mostly herbs are used in different ways like tea. Herbs and flowers are not only use as beverage but also use for the treatment of the disease or disorders. All of them a most beneficial herb that is use for the human health but also use in different medical therapies that is chamomile [1]. It is not important that everyone should know about all herbs but some specific herbs that have therapeutic effect should be in mind like chamomile. It's known as the medical plant in the medical field [2]. There are many research which discuss the treatment of dysmenorrhea with herbs such as chamomile. These research show that chamomile reduces mensuration cramps, anxiety and relieves pain in constipation. Now days there is more trend of treating dysmenorrhea by non-pharmacological ways which includes intake of herbs like chamomile, ginger , fennel and many more. But detailed studies of their effects are to be studied more [3].

\section{History of Chamomile}

Matricaria Chamomile and Chamomile Recutita are the scientific name of Chamomile two species. It's belongs to Asteracea family. These both herbs have same appearance and chemical properties [4]. It's growing in different countries like German, Russia, India and Brazil. According to a survey chamomile tea is used in German in tons annually. It's largest plant that is used in medical field and almost 1 million cups drink in a day. Chamomile is used for their remarkable characteristics, it mainly used for the spasms, antiinflammatory and menstrual disorder [5]. In the history medical plants use first time in Nagpur 5000 years ago with different recipes. With the passage of time different plants and medicines discover almost 944 drugs and 657 medical plants originate. In all of them a medical plant discovers that can use for different medical therapies. Chamaemelon name is used for the chamomile (Matricaria Rectita L.). This herb used for the different purpose like burn, cure wound, ulcer, for treating ENT. According to Dioscorides 
deemed chamomile flower is used for the treatment of menstrual problems, releases of embryo and for uterine problems [6].

\section{Properties of Chamomile}

Chamomile has different characteristics that make it most effective plant in the medical field. This medical plant has different abilities to treat disease and help in the maintenance of the health. Chamomile most effect species are M. chamomilla L. chamomile has anti-inflammatory. Anti-bacterial, anti-septic and anti- microbial properties [7]. Almost 9,500 death cause by cancer every year in the United States of America. A study was conducted in 2013 to find out anti- cancer properties of chamomile. The result showed that chamomile had a anti-oxidant properties antioxidants active compounds present in the chamomile [8]. Chamomile is also known as the miracle plant because of its properties. Chamomile is used for different purpose like anti-diuretic, for treating stomach aches, reduction of the dysmenorrhea, anti-allergens, anti-malaria, anti-fever and for the jaundice. Chamomile tea used during menstruation for lower the severity of the pain. Chamomile oil can be used to relive pain in the ear. Chamomile has therapeutic effects that boost up the immune system and help to fight with natives. Chamomile has ability to reduce eczema and treat acne [9]. A study was supervised to investigate the chamomile effect to reduce pain. 90 students containing participants divided into two groups. 100 mg Chamomile capsule and 250mg mefenamic acid capsule was given to the participants 3 times a day. The result was that intake of chamomile capsule lower the intensity of pain [10]. Chamomile is herbal medicine with anti-inflammatory effects, sedative effects, anti-anxiety effects and antispasmodic effects. Chamomile shows the higher rate of improvement in dysmenorrhea rather than the placebo it is more effective to relieve dysmenorrhea if use one day before your menstrual date [11].

\section{Dysmenorrhea}

Dysmenorrhea is menstrual pain, not a disease, it is a condition by which women feel discomfort periodically in their menstrual cycle [12]. Dysmenorrhea is a painful sensation in lower part of abdomen and it's commonly occurring in females of reproductive age. It may be due to family history and physiological changes and called as primary dysmenorrhea, it may be occurred due to the other gynecological problems that is secondary dysmenorrhea [13] (Figure 1).

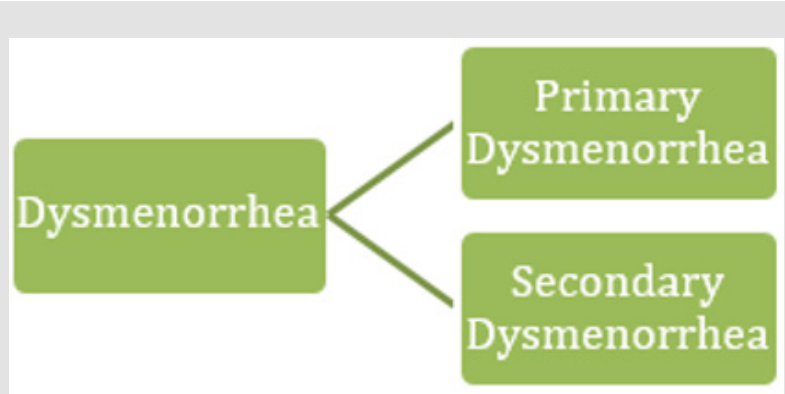

Figure 1: Types of Dysmenorrhea.

\section{Prevalence of Dysmenorrhea}

The prevalence of the dysmenorrhea is $50-90 \%$ according to another study and in Iran and America almost 74 to $80 \%$ and $60 \%$ women suffer from these conditions respectively [9]. Prevalence of dysmenorrhea is increasing day by day; it may cause of absentees in the schools. Dysmenorrhea not prevailed in just adult women but also alarmingly in schoolgirls. According to Agarwal et al., 2010, 79\% female reported by dysmenorrhea in which 37\% were absents from school due to severe menstrual pain [14]. To evaluate the prevalence of dysmenorrhea in Mexican university students a survey was conducted. Data were collected through questionnaire from 1539 students. Results showed that 64\% students were experiencing dysmenorrhea among which $36.1 \%$ were having mild, 43.8\% moderate and $20.1 \%$ were having severe menstrual pain [15]. According to a survey conducted on social media; Facebook, almost 88\% women were suffering from dysmenorrhea and only $34 \%$ were consulting health care and $86 \%$ participants were having alternative sources to reduce their pain [16]. According to another study, menstrual pain effect women health and it affects the mental health of the students also. So students should aware with their consequences [17].

According to Grandi and his colleagues reported $84.1 \%$ women suffering with menstrual pain, among university students. They concluded that dysmenorrhea is alarmingly accelerating now a days, women should be aware of with this and consider medical therapy [18]. A study conducted on King abdulaziz university students revealed that prevalence of dysmenorrhea in KAU was $60.9 \%$, which was not acceptable because of the health effects. In response to this university management held awareness seminars and conferences for the reduction of dysmenorrhea [19].

\section{Chamomile for the Treatment of Dysmenorrhea}

Chamomile is a herbal plant which is used for medicinal purposes because it has anti-inflammatory, anti-anxiety and stress reliever effects so that it is more effective in dysmenorrhea and other gynecological issue [20]. Capsule of matricaria chamomilla helps to reduce the level of severity of dysmenorrhea. So that chamomile is used to treat common female gynecological problem [21]. Chamomile is a herbal plant which is used for medicinal purposes because it has anti-inflammatory, anti-anxiety and stress reliever effects so that it is more effective in dysmenorrhea and other gynecological issue. The treatment of dysmenorrhea is effectively possible through herbs [22]. Mittal discussed that women are using contemporary therapies to treat dysmenorrhea which includes herbal therapy (use of chamomile in form of tea and essential oil), physiotherapy, yoga and heat. As medicines such as non-steroidal anti-inflammatory drugs and oral contraceptives are not always effective in treating dysmenorrhea so other methods to be used such as herbs [23]. In a study effect of chamomile on dysmenorrhea was compared with homeopathic similimum. 30 females of 18-30 years old participated in the study, for 3 months and 3 follow up were taken. Results revealed that chamomile as 
homeopathic complex and homeopathic similimum both were effective for the reduction of severity of pain [24].

Another study explored for the treatment of the dysmenorrhea. And it was reported that medical plants (chamomile, fennel and ginger) had ability to reduce dysmenorrhea level [25]. Another study analyzed the herbal association of dysmenorrhea. Approximately 900 students with age of 12-18 years old were involved in the study, on the rural girls of Egypt. Almost 89.9\% students were suffering from dysmenorrhea and 78\% use herbal treatment. The herbal treatment that was suggested in which chamomile, cinnamon, fenugreek and green tea were reported. The findings of this study should be used on management and use herbal therapies [26]. Another study explained that apart from using NSAIDS and oral contraceptives use of herbs to treat dysmenorrhea is getting more importance as it relives periods cramps and other effects more easily than medicines. In this study it was also stated that nutritional needs like intake of magnesium, vitamin B6, Vitamin $\mathrm{A}$ and $\mathrm{E}$ along with other dietary modifications are to be made to treat dysmenorrhea [27]. Begum et al., 2016 stated that the use of allopathic medicines likes non- steroidal anti-inflammatory drugs and oral contraceptives have their own side effects and are less effective. So, there must be use of herbal medicines such as chamomile in form of tea and oil to treat dysmenorrhea. With this other herb may also be used which could have their own properties [28]. Another study investigated the association between gingerchamomile to reduce the dysmenorrhea. The medication that was given to the students had a great combination to check the most effective combination for reduction of dysmenorrhea. This combination was chamomile-honey, ginger-honey, chamomileginger and with mefenamic. This combination was given to the participants before 2 days from menstruation and then during menstruation for 3 days. The result concluded that gingerchamomile is the best combination that reduce dysmenorrhea [29].

The uses of chamomile are in medicine, agricultural use such as in foods and biochemical uses. However here we discuss only medicinal use as chamomile relives stress and anxiety, relieves periods cramps and dysmenorrhea symptoms, relieves pain in constipation. Chamomile is used as in tea, oil can be extracted which is of blue color and it is used in ointments and tablets. From chamomile essential oil is extracted from whole plant which is used as aromatic or medicinal purpose. As it can be put on skin which is absorbed and goes to bloodstream and relieves pain or reduces anxiety or the oil is smelled to relieve anxiety [30]. In order to investigate the effect of mefenamic acid and chamomile on dysmenorrhea, 80 students were selected. Before taking medicines on 1hour, 2-hour, 4 hour and 48 hours the intensity of pain was checked. The study concluded that chamomile capsule more effective and considerable. Chamomile capsule have ability to reduce dysmenorrhea [21]. In research conducted in 2018 in Iran stated that the hot temperament herbs have a positive effect on treating primary dysmenorrhea. The study stated that hot temperament herbs such as chamomile or ginger helps curing dysmenorrhea despite of herbs that are cold temperament. Apart from NSAIDS and oral contraceptives these herbs played role in curing dysmenorrhea [31]. Chang and Chen, in 2016 investigated the chamomile effect on sleeping issues related with the menstrual problem because it disturb hormones. These participants were divided into two groups one is controlled group and second were experimental group. The results showed that chamomile is good for the women. It reduced depression and control hormones [32].

\section{Primary Dysmenorrhea and Chamomile}

In primary dysmenorrhea there is not any type of abnormality and in secondary dysmenorrhea gynecological problems which causes pain and cramps. Primary dysmenorrhea must be linked with genetics, stress and type of body other than the levels of prostaglandins. Uterine muscles produce prostaglandins which produce severe muscle contractions in uterus when menstrual cycle occurs. There is not any strong evidence that may relate level of prostaglandins and menstrual pain. Sometimes women with high level have more cramps than women with lower level of prostaglandins [27]. A study was conducted to find out that chamomile tea effect on dysmenorrhea. 80 students participated in this study for a month before 1 week to menstruation in first five days of their periods to drink chamomile tea 2 times a day. These participants are divided randomly into two groups. They collect data through questionnaire with intervention in first and 3rd month. The result of the study revealed that chamomile tea is efficient for the primary dysmenorrhea and relief pain [33]. In another study the chamomile effect on dysmenorrhea were explored. 20 students were given yarrow $150 \mathrm{mg}$ capsules and 20 students were given $250 \mathrm{mg}$ chamomile capsule in every 8 hours. The result showed that both capsule have capability to reduce menstrual pain [34]. Almost $60-90 \%$ women face dysmenorrhea and want relief from this pain. According Gholami Z in 2015 chamomile tea could be effective for the primary dysmenorrhea and stated that chamomile tea reduces dysmenorrhea and protect from primary dysmenorrhea [35] .

\section{Secondary Dysmenorrhea and Chamomile}

Secondary dysmenorrhea causes by tumors in fibroid, pelvis infection and endometriosis. Females and adolescents suffer from dysmenorrhea for a few days in every month which is a gynecological problem. Normally dysmenorrhea is functional which may be linked with ovulation there is no complication regarding female reproduction [27]. During menstruation use chamomile as a tea, it may reduce the menstruation pain and cramps. Chamomile tea also help to reduce inflammation and digestive problems like, constipation [36]. Primary and secondary dysmenorrhea is the types of dysmenorrhea. Primary dysmenorrhea is most common but secondary dysmenorrhea cause due to pelvic problem it's not just menstrual pain. These both types dysmenorrhea severity can 
be reduce by using different herbal treatment like chamomile, reduction of dysmenorrhea [37] (Table 1). cinnamon, ginger and mint. These are effective remedies for the

Table 1: Epidemiological studies of chamomile for the treatment of Dysmenorrhea.

\begin{tabular}{|c|c|c|c|c|c|}
\hline Author's Name & Year & Objective & Data & Results & Reference \\
\hline $\begin{array}{l}\text { Jenabi, E and } \\
\text { Ebrahimzedah, } \\
\text { S. }\end{array}$ & 2010 & $\begin{array}{l}\text { Chamomile } \\
\text { effect on primary } \\
\text { dyemenorrhea }\end{array}$ & Sample size:80 University students & $\begin{array}{l}\text { Chamomile teas reduce pain and } \\
\text { effective for dysmenorrhea }\end{array}$ & {$[33]$} \\
\hline Radfar, S et al., & 2018 & $\begin{array}{l}\text { Chamomile and } \\
\text { yarrow capsule reduce } \\
\text { menstrual pain }\end{array}$ & $\begin{array}{c}\text { Sample size:50 students } \\
\text { Yarrow } 150 \mathrm{mg} \text { capsule }=20 \text { students } \\
\text { Chamomile } 250 \mathrm{mg} \text { capsule }=20 \text { students }\end{array}$ & $\begin{array}{c}\text { Both have severity Reduce } \\
\text { menstrual pain }\end{array}$ & {$[34]$} \\
\hline Ngoie CM & 2018 & $\begin{array}{l}\text { Comparison b/w } \\
\text { chamomile and } \\
\text { homeopathic } \\
\text { similimum }\end{array}$ & $\begin{array}{l}\text { Sample size: } 30 \\
\text { Age }=18-30 \text { years } \\
\text { University students }\end{array}$ & $\begin{array}{l}\text { Both are effective for the } \\
\text { reduction of primary } \\
\text { dysmenorrhea }\end{array}$ & {$[24]$} \\
\hline $\begin{array}{l}\text { Sharangi } \mathrm{AB} \text { and } \\
\text { Bhutia } \mathrm{PH}\end{array}$ & 2019 & $\begin{array}{l}\text { Treatment of } \\
\text { dysmenorrhea }\end{array}$ & $\begin{array}{c}\text { Sample size:303 } \\
\text { Duration: six months }\end{array}$ & $\begin{array}{l}\text { Medical plants like chamomile, } \\
\text { ginger and fennel reduce } \\
\text { menstrual pain }\end{array}$ & {$[25]$} \\
\hline Modarres, M et al., & 2011 & $\begin{array}{l}\text { Chamomile and } \\
\text { mefenamic acid } \\
\text { effect on primary } \\
\text { dysmenorrhea }\end{array}$ & $\begin{array}{l}\text { Sample size: } 80 \text { students } \\
\text { Chamomile in Capsule form } \\
\text { Studied } 6 \text { cycles }\end{array}$ & $\begin{array}{l}\text { Chamomile capsule have ability } \\
\text { to lower dysmenorrhea }\end{array}$ & {$[21]$} \\
\hline Yassin SA & 2012 & $\begin{array}{l}\text { Association of herbs } \\
\text { with dysmenorrhea }\end{array}$ & $\begin{array}{c}\text { Sample size: } 900 \text { students age }=12- \\
18 \text { years }\end{array}$ & $\begin{array}{l}\text { Herbal treatment effective } \\
\text { mostly used }\end{array}$ & {$[26]$} \\
\hline $\begin{array}{l}\text { Shabani F and } \\
\text { Zareian MA }\end{array}$ & 2020 & $\begin{array}{l}\text { Ginger-chamomile } \\
\text { combination for } \\
\text { reduction } \\
\text { Dysmenorrhea }\end{array}$ & Sample size: 400 students & $\begin{array}{l}\text { This combination is better than } \\
\text { mefenamic acid }\end{array}$ & {$[29]$} \\
\hline
\end{tabular}

\section{Conclusion}

Chamomile is sweet and small flowers which reduce inflammation in our body and it also have anticonvulsant properties. Chamomile is used for their remarkable characteristics, it mainly used for the spasms, anti-inflammatory, effects so that it is more effective in dysmenorrhea and other gynecological issue. Dysmenorrhea is a painful sensation in lower part of abdomen and it's commonly occurring in females of reproductive age. Chamomile is effective for dysmenorrhea and relief pain. It has ability to reduce the severity of dysmenorrhea.

\section{References}

1. Hug LA, Baker BJ, Anantharaman K, Brown CT, Probst AJ, et al. (2016) A new view of the tree of life. Nature microbiology 1(5): 1-6.

2. Ravikumar C (2014) Review on herbal teas. Journal of Pharmaceutical Sciences and Research 6(5): 236.

3. Aksu H, Özsoy S (2016) Primary dysmenorrhea and herbals. Journal of Healthcare Communications 1(3): 23.

4. Zadeh JB, Kor NM, Kor ZM (2014) Chamomile (Matricaria recutita) as a valuable medicinal plant. International journal of Advanced Biological and Biomedical Research 2(3): 823-829.

5. Raal A, Orav A, Püssa T, Valner C, Malmiste B, et al. (2012) Content of essential oil, terpenoids and polyphenols in commercial chamomile (Chamomilla recutita L. Rauschert) teas from different countries. Food Chemistry 131(2): 632-638.
6. Petrovska BB (2012) Historical review of medicinal plants' usage. Pharmacognosy reviews 6(11): 1

7. Sharafzadeh S, Alizadeh O (2011) German and Roman chamomile. Journal of applied pharmaceutical science 1(10): 01-5.

8. Mamalis A, Nguyen DH, Brody N, Jagdeo J (20-13) The active natural antioxidant properties of chamomile, milk thistle, and halophilic bacterial components in human skin in vitro. Journal of drugs in dermatology JDD 12(7): 780-784

9. Bahmani M, Eftekhari Z, Jelodari M, Saki K, Abdollahi R, et al. (2015) Effect of Iranian herbal medicines in dysmenorrhea phytotherapy. Journal of Chemical and Pharmaceutical Research (2): 519-526.

10. Sharifi F, Simbar M, Mojab F, Alavi Majd H (2014b) Comparison of the effects of Matricaria chamomila (Chamomile) extract and mefenamic acid on the intensity of mastalgia associated with premenstrual syndrome. Women's Health Bulletin 1(2): 1-5.

11. Mirabi P, Alamolhoda SH, Esmaeilzadeh S, Mojab F (2014) Effect of medicinal herbs on primary dysmenorrhoea-a systematic review. Iranian journal of pharmaceutical research IJPR 13(3): 757.

12. Song JA, Lee MK, Min E, Kim ME, et al. (2018) Effects of aromatherapy on dysmenorrhea: A systematic review and meta-analysis. International journal of nursing studies 84: 1-1.

13. Ryan SA (2017) The treatment of dysmenorrea. Pediatric Clinics 64(2): 331-342.

14. Agarwal AK, Agarwal A (2010) A study of dysmenorrhea during menstruation in adolescent girls. Indian journal of community medicine: official publication of Indian Association of Preventive \& Social Medicine 35(1): 159. 
15. Ortiz MI (2010) Primary dysmenorrhea among Mexican university students: prevalence, impact and treatment. European Journal of Obstetrics \& Gynecology and Reproductive Biology 152(1): 73-77.

16. Subasinghe AK, Happo L, Jayasinghe YL, Garland SM, Gorelik A, et al (2016) Prevalence and severity of dysmenorrhoea, and management options reported by young Australian women. Australian Journal of General Practice 45(11): 829.

17. Aziato L, Dedey F, Clegg Lamptey JN (2014) The experience of dysmenorrhoea among Ghanaian senior high and university students: pain characteristics and effects. Reproductive health 11(1): 1-8.

18. Grandi G, Ferrari S, Xholli A, Cannoletta M, Palma F, et al. (2012) Prevalence of menstrual pain in young women: what is dysmenorrhea? Journal of pain research 5: 169.

19. Ibrahim NK, AlGhamdi MS, Al Shaibani AN, AlAmri FA, Alharbi HA, et al. (2015) Dysmenorrhea among female medical students in King Abdulaziz University: Prevalence, Predictors and outcome. Pakistan journal of medical sciences 31(6): 1312.

20. De Sanctis V, Soliman A, Bernasconi S, Bianchin L, Bona G, et al. (2015) Primary Dysmenorrhea in Adolescents: Prevalence, Impact and Recent Knowledge. Pediatric endocrinology reviews: PER 13(2): 512-520.

21. Modarres M, Mirmohhamad AM, Oshrieh Z, Mehran A (2011) Comparison of the effect of Mefenamic Acid and Matricaria Camomilla Capsules on primary dysmenorrhea. JBUMS 13(3): 50-58.

22. Khalesi ZB, Beiranvand SP, Bokaie M (2019) Efficacy of Chamomile in the Treatment of Premenstrual Syndrome: A Systematic Review. Journal of pharmacopuncture 22(4): 204

23. Mittal R (2019) Role of contemporary therapy in treatment of dysmenorrhea. International Journal of Advance Research. Ideas and Innovations in Technology 5(1): 9-11.

24. Ngoie CM (2018) The efficacy of a homoeophathic complex (Angelica sinensis, Dioscorea villosa $6 \mathrm{cH}$, Matricaria chamomilla $6 \mathrm{cH}$, Viburnum opulus $6 \mathrm{cH}$, and Zingiber officinalis $6 \mathrm{cH}$ ) compared with homoeopathic similimum (30 $\mathrm{cH}$ plussed) in the treatment of primary dysmenorrhoea (Doctoral dissertation).

25. Sharangi AB, Bhutia PH (2016) Stevia: Medicinal Miracles and therapeutic magic. International Journal of Crop Science and Technology $2(2)$.

26. Yassin SA (2012) Herbal remedy used by rural adolescent girls with menstrual disorders. J Am Sci 8(1): 467-473.

\section{ISSN: 2574-1241}

DOI: $10.26717 /$ BJSTR.2021.34.005490

Sidra khalid. Biomed J Sci \& Tech Res

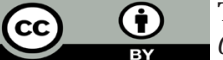

This work is licensed under Creative Commons Attribution 4.0 License

Submission Link: https://biomedres.us/submit-manuscript.php
27. Alsiyabi AI, Mullaicharam AR, Halligudi N (2016) A review on evaluation, management and pathophisiology of dysmenorrhea 5(5): 241-259.

28. Begum M, Das S, Sharma HK (2016) Menstrual disorders: causes and natural remedies. Journal of Pharmaceutical, Chemical and Biological Sciences 4(2): 307-320.

29. Shabani F, Zareian MA (2020) Evaluation of the Possibility of Synergism of Medicinal Effects of Chamomile and Ginger on Pain and Symptoms of Primary Dysmenorrhea: A Randomized Controlled Trial. Complementary Medicine Journal 9(4): 3852-3867.

30. Das M (2014) Chamomile: medicinal, biochemical, and agricultural aspects. CRC Press.

31. Rajabzadeh F, Fazljou SM, Khodaie L, Abbasalizadeh S, Sahebi L (2018) Effects of hot temperament herbs on primary Dysmenorrhea: a systematic review. World Family Medicine Journal: Incorporating the Middle East Journal of Family Medicine 99(5897): 1-7.

32. Chang SM, Chen CH (2016) Effects of an intervention with drinking chamomile tea on sleep quality and depression in sleep disturbed postnatal women: a randomized controlled trial. Journal of advanced nursing 72(2): 306-315.

33. Jenabi E, Ebrahimzadeh S (2010) Chamomile tea for relief of primary dysmenorrhea. Iranian Journal of Obstetrics, Gynecology and Infertility 13(1): 39-42.

34. Radfar S, Shahoie R, Noori B, Jalilian F, Nasab LH (2018) Comparative Study on the Effect of Matricaria chamomile and Achillea millefolium Capsules on Primary Dysmenorrhea Intensity of Dormitory Students of Kurdistan University of Medical Sciences. Journal of Pharmaceutical Research International 25(3): 1-7.

35. Gholami Z (2015) The primary dysmenorrhea and complementary medicine in Iran: A systematic review. International Journal of Fertility \& Sterility 9: 107.

36. Kashani L, Mohammadi M, Heidari M, Akhondzadeh S (2015) Herbal medicine in the treatment of primary dysmenorrhea 14: 53-58.

37. Sharifi F, Simbar M, Mojab F, Alavi Majd H (2014a) Comparison of the effects of Matricaria chamomila (Chamomile) extract and mefenamic acid on the intensity of mastalgia associated with premenstrual syndrome. Women's Health Bulletin 1(2): 1-5.

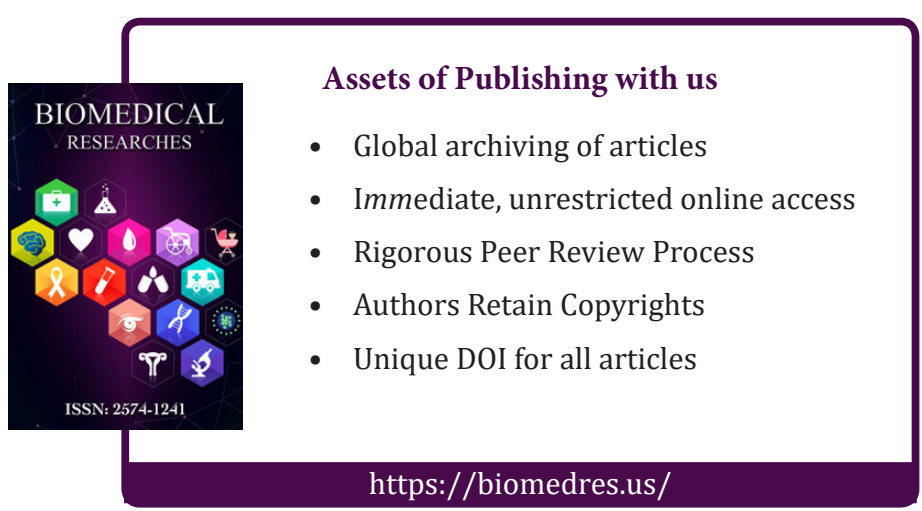

